\title{
Investigation of the Polymorphic Region in the 5' Flanking Region of the Insulin Gene in Patients with Alzheimer's Disease
}

\author{
Michael Fisman and Valerie M. Watt
}

\begin{abstract}
A potential relationship between Alzheimer's Disease (AD) and insulin gene expression was suggested by the observation that patients with AD have altered levels of fasting blood sugar and insulin. Since polymorphisms in the region $5^{\prime}$ to the insulin gene have been associated with blood glucose levels, we have studied this polymorphism in AD patients. Subjects were 19 nondiabetic AD patients with symptoms of aphasia and apraxia and a family history of $\mathrm{AD}$; and 20 age and sex-matched nondiabetic controls without family history of AD. The 5' polymorphic region of the insulin gene was analyzed by restriction enzyme digestion of DNA extracted from whole venous blood. We did not observe a correlation between the size of the $5^{\prime}$ polymorphic region and AD.
\end{abstract}

\begin{abstract}
RÉSUMÉ: Investigation de la région polymorphique adjacente en $5^{\prime}$ au gène de l'insuline chez des patients atteints de la maladie d'Alzheimer. L'observation que les patients atteints de la maladie d'Alzheimer (MA) ont des modifications du taux sanguin de sucre et d'insuline nous autorise à penser qu'il existe peut-être une relation entre la MA et l'expression du gène de l'insuline. Comme les polymorphismes dans la région située en 5 ' du gène de l'insuline ont été associés avec les taux sanguins de glucose, nous avons étudié ce polymorphisme chez les patients atteints de MA. Nous avons choisi 19 patients non-diabétiques atteints de MA qui présentaient des symptômes d'aphasie et d'apraxie, avec une histoire familiale de MA, et 20 témoins non-diabétiques appariés pour l'âge et le sexe, sans histoire familiale de MA. La région polymorphique située en 5' du gène de l'insuline a été analysée par digestion au moyen d'enzymes de restriction de l'ADN extrait de sang complet obtenu par ponction veineuse. Nous n'avons pas observé de corrélation entre la taille de la région polymorphique en 5' et la MA.
\end{abstract}

Can. J. Neurol. Sci. 1986; 13:471-474

Alterations in glucose and insulin metabolism occur in Alzheimer's Disease (AD). Bucht et al ${ }^{1}$ reported significantly elevated insulin and reduced glucose levels in the blood of $\mathrm{AD}$ patients compared to controls following an oral glucose tolerance test. Following a 24 hour fast, Fisman et $\mathrm{al}^{2}$ reported significantly reduced insulin and elevated glucose in the blood of $A D$ patients relative to a healthy control group. In addition, AD patients exhibit reduced cerebral utilization of glucose as measured by PET scanning. ${ }^{3}$ Paradoxically, biopsy specimens from AD patients exhibit unaltered or even enhanced glucose utilization in vitro. ${ }^{4}$

Blood glucose levels vary with specific restriction fragment length polymorphisms (RFLPs) in the $5^{\prime}$ flanking region of the human insulin gene, ${ }^{5}$ although insulin secretion ${ }^{6}$ and insulin gene expression ${ }^{7}$ do not. Since a correlation between this RFLP and $A D$ might provide a means to identify the locus for $A D$, we investigated the association between the RFLP 5 ' to the insulin gene and familial AD.

\section{METHODS}

\begin{abstract}
Subjects
The subjects for investigation were hospitalized $A D$ patients and community controls (Table 1). The AD patients presented with clinical findings compatible with the clinical description of AD. ${ }^{8}$ Specific inclusion criteria included a history characterized by progressive, intellectual decline in the absence of other major illness or precipitating factors, aphasia and family history of parents (and siblings) with illness compatible with a diagnosis of AD. Exclusion criteria included atypical cases, cases with a fluctuating or nonprogressive course, as well as the clinical history or findings of alcoholism, cerebrovascular accident, primary psychotic illness, mental retardation, brain trauma, malignancy and other major organic illness. All patients were examined by an internist and psychiatrist and a standard battery of laboratory investigations was performed. Of 42 patients selected for the study as suffering from $A D$, only 19 met the
\end{abstract}


additional criteria of aphasia and probable positive history of $\mathrm{AD}$ in parents. Informed consent to participate in the trial was obtained from next of kin.

The control group comprised 20 volunteers living independently in the community, free from any major illness including diabetes and stroke. These control subjects had no family history of dementing illness in parents or siblings and were able to answer correctly a short mental status questionnaire.

\section{DNA manipulation}

Approximately $40 \mathrm{ml}$ of venous blood was collected from each subject into tubes treated with EDTA and stored at $4^{\circ} \mathrm{C}$. For DNA preparation, nuclei were isolated from white blood cells by centrifugation of the peripheral blood. DNA was extracted from the nuclei as described by Wigler et al. ${ }^{9}$ Approximately $7 \mathrm{ug}$ of DNA was digested with Sst 1 (45 U) for $19 \mathrm{~h}$, subjected to agarose gel electrophoresis and blotted onto nitrocellulose filters. ${ }^{10}$ The filters were then hybridized with the human insulin gene fragment (see Figure 1) which had been radioactively labelled with ${ }^{32} \mathrm{P}$-CTP by nick translation. " Hybridization was carried out at $42^{\circ} \mathrm{C}$ overnight in the following solution: $50 \%$ formamide; $0.75 \mathrm{M}$ sodium chloride; $75 \mathrm{mM}$ sodium citrate; $0.01 \%$ bovine serumalbumin; $0.01 \%$ ficoll; $0.01 \%$ polyvinyl pyroldone; $200 \mathrm{ug} / \mathrm{ml}$ salmon sperm DNA; $0.02 \mathrm{M} \mathrm{NaPO}_{4}, \mathrm{pH} 6.8 ; 50 \%$ dextran sulfate; and $2 \times 10^{5} \mathrm{cpm}$ insulin gene $/ \mathrm{ml}$. Filters were then washed in 15 $\mathrm{mM}$ sodium chloride; $1.5 \mathrm{mM}$ sodium citrate; $0.1 \%$ sodium dodecyl sulfate at $42^{\circ} \mathrm{C}$ for $2 \mathrm{~h}$ and then exposed to X-OMAT R film using an intensifying screen at $-70^{\circ} \mathrm{C}$ for $2 \mathrm{~d}$.

\section{Statistical Analysis}

The significance of differences between frequencies was evaluated using the chi-squared test.

\section{RESULTS}

We have studied the correlation between AD and the polymorphism 5 ' to the insulin gene, both of which have been associated with the levels of blood glucose. The patients exhibited classic symptoms of AD that appeared to be genetically inherited. In addition, senile plaques, neurofibrillary tangles and granulovacular changes characteristic of $\mathrm{AD}$ were observed at autopsy in the brain of the one patient examined. Controls were apparently healthy subjects that were age-and sex-matched to AD patients (Table 1 ).

The polymorphic region $5^{\prime}$ to the insulin gene was analyzed in DNA isolated both from Alzheimer's patients and controls. DNA was digested with the restriction enzyme Sst 1 to produce a fragment that contained the 5 ' polymorphic region and extended through the gene itself. The size of the DNA fragment containing the polymorphic region was determined by hybridization to the insulin gene probe shown in Figure 1. The exact size of this Sstl fragment is determined by the length of the polymorphic region. A representative autoradiograph illustrating the sizes of the hybridizing bands is shown in Figure 2. Lanes 1 to 3 and 5 display a restriction fragment of $5.5 \mathrm{~kb}$ that hybridizes to the insulin gene. This size has been designated class $1^{12}$ as shown in Figure 1. Lanes 1, 4 and 5 display a larger hybridizing band of $6.9 \mathrm{~kb}$ characteristic of the class 3 (Figure 1). No class 2 alleles, which are intermediate between class 1 and class $3,{ }^{12}$ were observed.
Table 1: Clinical features of subjects analyzed for polymorphisms adjacent to the insulin gene

\begin{tabular}{lccccc}
\hline \hline & & \multicolumn{2}{c}{ Sex } & \multicolumn{2}{c}{ Age (Years) } \\
& $\mathbf{n}$ & Male & Female & Mean & Range \\
\hline Controls & 20 & 8 & 12 & 71 & $58-91$ \\
AD & 19 & 6 & 13 & 76 & $67-84$ \\
\hline
\end{tabular}

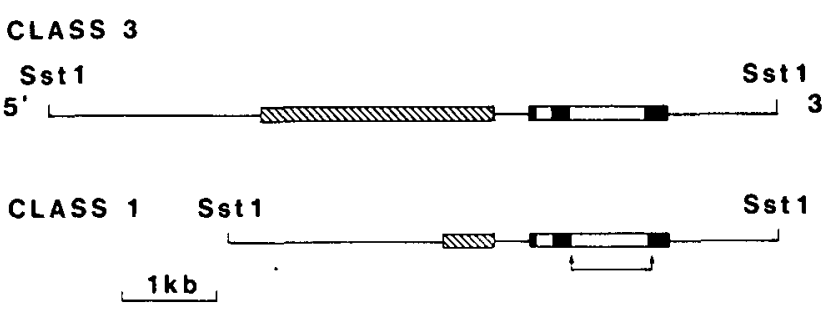

Figure 1 - Two allelic classes of the insulin gene. The site of the insulin gene is shown with the closed boxes indicating the introns and the open boxes indicating intervening sequences. The polymorphic regions are indicated by the hatched boxes. Also indicated are the positions of the restriction enzyme sites (Sstl) and the probe (between arrows) used for this analysis. 
Table 2: Frequencies of $5^{\prime}$ polymorphic regions ${ }^{+}$

\begin{tabular}{lccr}
\hline & & Allelic frequency & \\
\cline { 3 - 3 } & class 1 & class 2 & class 3 \\
\hline Control & $31(77.5)$ & $0(0)$ & $9(22.5)$ \\
AD & $26(68.4)$ & $0(0)$ & $12(31.6)$ \\
\hline \multicolumn{3}{c}{} & Genotypic Frequency \\
\cline { 3 - 3 } & $\mathbf{1 / 1}$ & $\mathbf{1 / 3}$ & $\mathbf{3 / 3}$ \\
\hline Control & $12(60.0)$ & $7(35.0)$ & $1(5.0)$ \\
$\mathrm{AD}$ & $9(47.4)$ & $\mathbf{8 ( 4 2 . 1 )}$ & $2(10.5)$ \\
\hline
\end{tabular}

+ Percentages are shown in parentheses.

The frequencies of occurrence of each allele in both the controls and the $\mathrm{AD}$ group are shown in Table 2. The frequencies of the different allelic classes did not differ significantly between the control group and the AD group $(p=0.2)$. Both groups showed non-random assortment of alleles, however, with class 1 predominating over class 3 and with an absence of class 2 . It had previously been shown that the allelic frequencies of the $5^{\prime}$ insulin gene polymorphism are racially dependent. ${ }^{12}$ The allelic frequencies we observed in our Caucasian population agree with earlier results obtained for a Caucasian population by Bell et al. ${ }^{12}$

The polymorphism $5^{\prime}$ to the insulin gene was also analyzed using genotypic frequencies. Representative restriction enzyme analysis of the three genotypes we observed are shown in Figure 2: 1,1 with two class 1 alleles (lanes 2, 3); 1,3 with one class 1 allele and one class 3 allele (lanes 1, 5); and 3,3 with two class 3 alleles (lane 4). The genotypic frequencies, as with the allelic frequencies, did not differ significantly between the control group and the AD group ( $p=0.5$; Table 2 ). Consistent with the results involving determination of the allelic frequencies, there were significant differences in the distributions of the genotypes. Genotype 1,1 was most common and genotype 3,3 was least common.

\section{Discussion}

The alteration in glucose and insulin metabolism in $\mathrm{AD}$ prompted us to screen AD patients for polymorphisms $5^{\prime}$ to the insulin gene which had previously been associated with blood glucose levels. ${ }^{5}$ The occurrence of the two alleles which we observed, class 1 and class 3 , did not correlate with AD. Similarily, none of the three genotypes (classes 1 and 3, class 1 alone, class 3 alone) correlated with $\mathrm{AD}$. Thus, an association between this polymorphism and $\mathrm{AD}$ was not observed.

Although increased recombination at the polymorphic region $5^{\prime}$ to the insulin gene ${ }^{13}$ may have obscured an association between this region and $\mathrm{AD}$, this polymorphism has previously been shown to be associated with several other diseases with altered fuel metabolism. A higher frequency of the class 1 allele has been found repeatedly in association with insulin-dependent diabetes mellitus. ${ }^{12,14}$ Although a higher prevalence of the class 3 allele was initially found in noninsulin-dependent diabetes mellitus, ${ }^{15}$ sampling of larger and varied populations has not supported this conclusion. ${ }^{14}$ The class 3 allele does appear to be associated with hypertriglyceridemia ${ }^{16}$ and atherosclerosis. ${ }^{17.18}$ The association between class 3 alleles and atherosclerotic or atherogenic disease may enable this polymorphic region to be used to differentiate between $A D$ and multi-infarct dementia (MID) since HDL levels are normal in patients with $A D$ and reduced in patients with MID. ${ }^{19}$

Despite clinical evidence for an hereditary component in AD compatible with a dominant mode of inheritance, ${ }^{20.21}$ no genetic locus for $\mathrm{AD}$ has thus far been identified. The results of previous studies analyzing the linkage between $\mathrm{AD}$ and other phenotypic gene markers are conflicting or inconclusive ${ }^{20.22-24}$ The failure of our study to detect a genetic locus may reflect genetic heterogeneity in $\mathrm{AD}$, the difficulty of establishing a family history in the absence of autopsy evidence of $A D$ and the very limited genetic studies undertaken so far in AD. Further genetic studies of families informative for AD utilizing random RFLPs to systematically localize the gene involved in AD may prove more useful. This approach has proven fruitful for other genetically inherited diseases such as Huntington's chorea. ${ }^{25}$

\section{ACKNOWLEDGEMENTS}

We thank Peter Shier and Lucie Koubek for technical assistance, Rachel Syme and Elaine Cudmore for secretarial assistance and C.J. Ingles, J. Segall and D. Crapper-McLachlan for critical reading of this manuscript. This work was funded by grants from the Canadian Diabetes Association and the Medical Research Council of Canada to VMW.

\section{REFERENCES}

1. Bucht G, Adolfsson R, Lithner F, et al. Changes in blood glucose and insulin secretion in patients with senile dementia of Alzheimer type. Acta Med Scand 1983; 213: 387-392.

2. Fisman M, Gordon B, MacDonald T, et al. Carbohydrate metabolism in Alzheimer's disease. 138th Meeting of the Am Psych Assoc Dallas 1985. p42.

3. Benson DF. Alterations in glucose metabolism in Alzheimer's disease. In: Katzman R, ed. Biological Aspects of Alzheimer's Disease Banbury Reports. Cold Spring Harbour Laboratories, 1983: 309-315.

4. Bowen DM. Biochemical assessment of neurotransmitter and metabolic dysfunction and cerebral atrophy in Alzheimer's disease. In: Katzman R, ed. Biological Aspects of Alzheimer's Disease Banbury Reports. Cold Spring Harbour Laboratories, 1983: 219-229.

5. Owerbach D, Poulsen S, Billesbolle P, et al. DNA insertion sequences near the insulin gene affect glucose regulation. Lancet 1982; April 17: 880-882.

6. Permutt MA, Rotwein P, Andreone T, et al. Islet B-cell function and polymorphism in the $5^{\prime}$-flanking region of the human insulin gene. Diabetes 1985; 34: 311-314.

7. Walker MD, Edlund T, Boulet AM, et al. Cell-specific expression controlled by the 5 -flanking region of insulin and chymotrypsin genes. Nature 1983; 306: 557-661.

8. Slater E, Roth M. Clinical Psychiatry. Bailliere, Tindall (London) 1979; 533-630.

9. Wigler M, Sweet R, Sim GK, et al. Transformation of mammalian cells with genes from procaryotes and eucaryotes. Cell 1979; 16: 777-785.

10.. Southern EM. Detection of specific sequences among DNA fragments separated by gel electrophoresis. J Mol Biol 1975; 98: 503-517.

11. Rigby PWJ, Dieckmann M, Rhodes C, et al. Labeling desoxyribnucleic acid to high specific activity in vitro by nick translation with DNA polymerase I. J Mol Biol 1977; 113: 237-251.

12. Bell GI, Horita S, Karam JH. A polymorphic locus near the human insulin gene is associated with insulin-dependent diabetes mellitus. Diabetes 1984; 33: 176-183.

13. Chakravarti A, Elbein SC, Permutt MA. Evidence for increased recombination near the human insulin gene: implication for disease association studies. Proc Natl Acad Sci USA 1986; 83: 1045-1049. 
14. Permutt MA, Andreone T, Chirgwin J, et al. Insulin gene polymorphism and Type II or non-insulin dependent Diabetes mellitus (NIDDM). In: Labrie F and Proulx L, eds. Proceedings of the Seventh International Congress on Endocrinology. Excerpta Medica, New York, 1985: 245-248.

15. Owerbach D, Nerup J. Restriction fragment length polymorphism of the insulin gene in diabetes mellitus. Diabetes 1982; 21 : 275-277.

16. Jowett NI, Williams LG, Hitman GA, et al. Diabetic hypertriglyceridaemia and related 5 ' flanking polymorphism of the human insulin gene. Brit Med J 1984; 288: 96-99.

17. Mandrup-Poulsen T, Owerbach D, Mortensen SA, et al. DNA sequences flanking the insulin gene on chromosome 11 confer risk of atherosclerosis. Lancet 1984; February 4: 250-252.

18. Owerbach D, Johansen K, Billesbolle $P$, et al. Possible association between DNA sequences flanking the insulin gene and atherosclerosis. Lancet 1982; December 11: 1291-1293.

19. Muckle TJ, Roy JR. High-density lipoprotein cholesterol in differential diagnosis of senile dementia. Lancet 1985; May 25: 1191-1192.
20. Goudsmit J, White BJ, Weitkamp LR, et al. Familial Alzheimer's disease in two kindreds of the same geographic and ethnic origin. J Neurol Sci 1981; 49: 79-89.

21. Breitner JCS, Folstein MF. Familial Alzheimer dementia: a prevalent disorder with specific clinical features. Psychol Med 1984; 14: 63-80.

22. Wilcox CB, Caspary EA, Behan PO. Histocompatibility antigens in Alzheimer's disease. Eur Neurol 1980; 19: 262-265.

23. Reisner E, Heyman A, Weinberg $T$, et al. Lack of association between Azheimer's disease and histocompatibility antigens. Tissue Antigens 1983; 21: 31-34.

24. Spence MA, Heyman A, Marazita ML, et al. Genetic linkage studies in Alzheimer's disease. Neurology 1986; 36: 581-584.

25. Gusella JF, Wexler NS, Conneally PM, et al. A polymorphic DNA marker genetically linked to Huntington's disease. Nature 1983; 306: 234-238. 